\title{
DAMPAK FENOMENA EL NINO TERHADAP PENDAPATAN USAHATANI DAN POLA TANAM PETANI PADI DI KECAMATAN NATAR KABUPATEN LAMPUNG SELATAN
}

\author{
(The Impact of El Nino Phenomenon on Farming Income and Cropping Pattern of Rice Farmers in Natar \\ Subdistrict South Lampung Regency)
}

Tri Nugroho, Zainal Abidin, Lina Marlina

Jurusan Agribisnis, Fakultas Pertanian, Universitas Lampung, Jl. Prof. Dr. Soemantri Brojonegoro No. 1 Bandar Lampung 35145, Telp. 085769941833, e-mail: trinugroho_smanda@yahoo.com

\begin{abstract}
The purposes of this research are to analyze the impact of El Nino phenomenon in 2015 on rice farming income and on cropping pattern of farmers and to figure out mitigation efforts of farmers to anticipate the impact of the phenomenon. This research was conducted in two villages in Natar Subdistrict South Lampung Regency in August - November 2016. They are Pancasila Village which represents a pump irrigation area and Negararatu Village represents a technical irrigation area. Respondents were 76 rice farmers who were chosen simply randomly. The study used a quantitative descriptive analysis method. The study showed that El Nino phenomenon had no effect on farming income, and on cropping pattern. Farmers mitigated by increasing the costs of water pump.
\end{abstract}

Key words: cropping pattern, el Nino, farming income, mitigation

\section{PENDAHULUAN}

Menurut BMKG (2015), Saat ini telah banyak terjadi perubahan iklim yang disebabkan oleh aktivitas manusia ataupun oleh alam. Fenomena El Nino kini terjadi pada tahun 2015. El Nino adalah gejala penyimpangan kondisi laut yang ditandai dengan meningkatnya suhu permukaan laut (sea surface temperature-SST) di Samudera Pasifik sekitar equator (equatorial pacific), khususnya di bagian tengah dan timur (sekitar pantai Peru). Lautan dan atmosfer adalah dua sistem yang saling terhubung, maka penyimpangan kondisi laut ini menyebabkan terjadinya penyimpangan pada kondisi atmosfer, yang pada akhirnya berakibat pada terjadinya penyimpangan iklim.

Menurut BMKG (2015), El Nino Moderate diperkirakan berlangsung dari bulan Juni 2015 hingga November 2015. Daerah yang berpotensi terkena dampak El Nino meliputi Sumatera Selatan, Lampung, Jawa, Bali, Nusa Tenggara, Sulawesi Selatan, dan Sulawesi Utara. Sebagai sektor yang sangat dipengaruhi oleh iklim, pertanian di Indonesia merupakan sektor yang akan merasakan dampak dari fenomena El Nino ini. Mengingat bahwa sektor pertanian dan iklim adalah dua hal yang saling berkaitan, tentunya fenomena El Nino yang terjadi akan mempengaruhi aktivitas budidaya tanaman pangan khususnya tanaman padi di Indonesia.
Provinsi Lampung merupakan salah satu daerah lumbung pangan yang turut berkontribusi terhadap produksi nasional tanaman pangan khususnya produksi tanaman padi. Terjadinya fenomena El Nino pada tahun 2015 di Provinsi Lampung dapat dilihat dari penurunan tingkat curah hujan yang terjadi pada bulan Mei hingga Desember tahun 2015 yang dibandingkan dengan tingkat curah hujan pada dua tahun sebelumnya yang tertera pada Gambar 1.

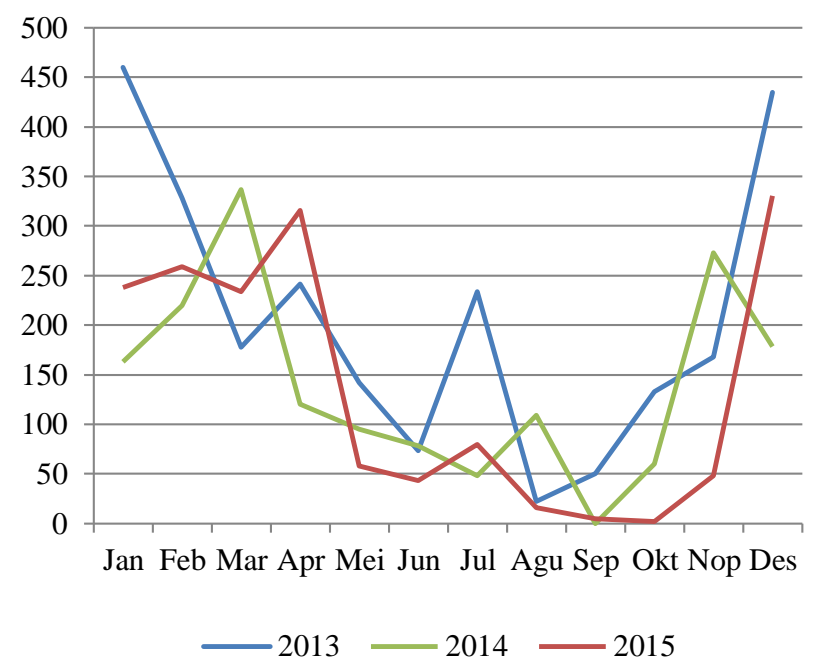

Sumber: Badan Meteorologi Klimatologi dan Geofisika Provinsi Lampung (2015)

Gambar 1. Grafik curah hujan (mm) Provinsi Lampung tahun 2013-2015 
Tabel 1. Produksi padi menurut Kecamatan di Kabupaten Lampung Selatan tahun 2014 dan 2015

\begin{tabular}{|c|c|c|c|c|}
\hline \multirow{3}{*}{ Kecamatan } & \multicolumn{4}{|c|}{ Produksi Padi (Ton) } \\
\hline & \multicolumn{2}{|c|}{2014} & \multicolumn{2}{|c|}{2015} \\
\hline & $\begin{array}{c}\text { Padi } \\
\text { Sawah }\end{array}$ & $\begin{array}{c}\text { Padi } \\
\text { Ladang }\end{array}$ & $\begin{array}{c}\text { Padi } \\
\text { Sawah }\end{array}$ & $\begin{array}{c}\text { Padi } \\
\text { Ladang }\end{array}$ \\
\hline Natar & 46.468 & 1.964 & 45.281 & 301 \\
\hline Jati Agung & 28.871 & 2.014 & 29.513 & 1.054 \\
\hline Tanjung Bintang & 17.081 & 2.552 & 14.577 & 2.212 \\
\hline Tanjung Sari & 7.522 & 1.743 & 8.695 & 1.821 \\
\hline Katibung & 10.124 & 4.966 & 9.653 & 3.389 \\
\hline Merbau Mataram & 16.251 & 1.467 & 15.546 & 765 \\
\hline Way Sulan & 18.294 & 1.766 & 16.388 & 1.105 \\
\hline Sidomulyo & 22.124 & 3.310 & 32.316 & 2.378 \\
\hline Candipuro & 56.077 & 665 & 59.564 & 452 \\
\hline Way Panji & 15.997 & 638 & 21.688 & 572 \\
\hline Kalianda & 31.877 & 4.737 & 28.743 & 4.274 \\
\hline Rajabasa & 8.757 & 1.346 & 14.842 & 346 \\
\hline Palas & 60.710 & 2.209 & 103.161 & 1.054 \\
\hline Sragi & 30.405 & 853 & 21.256 & 903 \\
\hline Penengahan & 25.556 & 2.115 & 32.725 & 1.806 \\
\hline Ketapang & 33.111 & 1.377 & 27.680 & 1.580 \\
\hline Bakauheni & 5.745 & 766 & 6.452 & 753 \\
\hline Lampung Selatan & 434.969 & 34.488 & 488.079 & 24.764 \\
\hline
\end{tabular}

Menurut BPS Provinsi Lampung (2015), Kabupaten Lampung Selatan merupakan salah satu penghasil tanaman padi terbesar di Provinsi Lampung. Berdasarkan Tabel 1 dapat dilihat bahwa terjadinya fenomena El Nino di Kabupaten Lampung Selatan ditandai dari penurunan produksi padi di sebagian besar Kecamatan di Kabupaten Lampung Selatan pada tahun 2015 yang dibandingkan dengan tahun 2014. Salah satu kecamatan di Kabupaten Lampung Selatan yang mengalami dampak dari fenomena El Nino dan sebagai salah satu penghasil tanaman padi adalah Kecamatan Natar.

Fenomena El Nino mulai muncul pada bulan Mei dan Juni tahun 2015, bertepatan dengan aktivitas usahatani padi pada MT 2. Penurunan tingkat curah hujan akibat fenomena El Nino berpengaruh terhadap ketersediaan air di lahan sawah. Ketika MT 2, kebutuhan air pada usahatani padi tidak lagi bergantung kepada curah hujan, melainkan bergantung pada sumber air yang ada di dekat lahan sawah yakni sumber air irigasi. Berdasarkan hal tersebut, maka hanya petani yang memiliki lahan sawah dengan sumber air irigasi yang dapat melakukan kegiatan usahatani padi pada MT 2, sedangkan petani dengan lahan sawah dengan sistem tadah hujan tidak bisa melakukan kegiatan usahatani padi, dikarenakan tidak memiliki sumber air irigasi. Beberapa Desa di Kecamatan Natar memiliki dua jenis sumber air irigasi yakni sumber air irigasi pompa dan sumber air irigasi teknis.
Menurut Irawan (2006), peluang produksi pangan (padi dan palawija) yang hilang akibat El Nino secara nasional menunjukkan terjadinya penurunan sebesar 2,43 persen. Menurut Utami, Jamhari dan Hardyastuti (2011), pada periode waktu 1987-2006 menunjukkan bahwa El Nino telah menyebabkan penurunan produksi padi yang lebih besar yakni rata-rata sebesar 4,15 persen dibanding saat normal.

Menurut Ariani (2011), dampak fenomena El Nino pada wilayah pertanaman padi sangat erat kaitannya dengan pola tanam dan perilaku petani. Pola tanam yang umum diikuti oleh petani di Jawa dan hampir seluruh wilayah Indonesia adalah padipadi-padi atau padi-padi-bera. Padi pertama ditanam pada musim hujan yaitu November/ Desember (MT 1), padi kedua pada awal masuk musim kemarau yaitu Maret/April (MT 2) dan padi ketiga pada bulan Juni/Juli (MT 3). Padi yang biasanya terkena kekeringan adalah padi yang ditanam pada musim kemarau.

Selanjutnya menurut Ariani (2011), fenomena El Nino pada tahun 1991/1992 terjadi pada saat petani sudah selesai melakukan penanaman, sehingga banyak yang tidak bisa diselamatkan lagi. Sebaliknya pada tahun 1997/1998, karena pembentukan El-Nino sangat cepat dan terjadi di awal musim kemarau, hujan pada musim kemarau sudah tidak ada, sehingga petani banyak yang tidak berani melakukan penanaman, khususnya pada musim kering (MK) 2. Segala dampak yang mungkin dapat terjadi akibat fenomena El Nino tentunya perlu dicegah dan diminimalisir. Petani sebagai pelaku utama diharapkan mampu melakukan upaya mitigasi guna keberlangsungan aktivitas usahataninya.

Berdasarkan penjelasan tersebut, penelitian ini bertujuan untuk mengetahui dampak fenomena El Nino terhadap pendapatan usahatani padi dan pola tanam petani serta mengetahui upaya mitigasi yang dilakukan petani dalam mengantisipasi dampak dari fenomena El Nino.

\section{METODE PENELITIAN}

Data di dalam penelitian diambil dari usahatani padi MT 2 pada tahun 2014 dan 2015 di dua desa di Kecamatan Natar, Kabupaten Lampung Selatan yang dipilih mewakili jenis-jenis irigasi lahan sawah yang ada. Kedua lokasi desa tersebut adalah Desa Pancasila mewakili lahan irigasi pompa dan Desa Negararatu mewakili lahan irigasi teknis. Metode penelitian yang digunakan adalah metode 
survei. Jenis data yang digunakan adalah data primer dan data sekunder yang dikumpulkan melalui proses observasi dan wawancara menggunakan kuisioner yang telah disiapkan. Data diolah dengan menggunakan metode analisis deskriptif kuantitatif. Teknik penentuan sampel dilakukan dengan menggunakan metode sampel acak sederhana (simple random sampling). Penentuan ukuran sampel dilakukan dengan menggunakan rumus perhitungan sampel menurut Frank Lynch dalam Sugiarto, Siagian, Sunarto dan Oetomo (2003) yakni sebanyak 76 sampel. Untuk melakukan pembagian ukuran sampel digunakan rumus alokasi proporsional yang hasilnya yakni sebanyak 44 sampel di lahan irigasi pompa dan 32 sampel di lahan irigasi teknis. Penelitian ini dilaksanakan pada bulan Agustus hingga November 2016.

Analisis deskriptif kuantitatif digunakan untuk mengetahui tingkat pendapatan dari usahatani padi. Proses perhitungan dilakukan dengan menggunakan rumus menurut Rahim dan Hastuti (2007) yakni sebagai berikut:

$$
\begin{array}{ll}
\pi & =\mathrm{TR}-\mathrm{TC}, \text { atau } \\
\pi & =\mathrm{Y} . \mathrm{Py}-\sum_{i-1}^{n} \mathrm{Xi} . \mathrm{Pxi}-\mathrm{BTT}
\end{array}
$$

Keterangan:

$\pi \quad=$ Keuntungan/ pendapatan $(\mathrm{Rp})$

$\mathrm{TR}=$ Total penerimaan $(\mathrm{Rp})$

$\mathrm{TC}=$ Total biaya $(\mathrm{Rp})$

$\mathrm{Y} \quad=$ Jumlah produksi (satuan)

Py = Harga satuan produksi $(\mathrm{Rp})$

$\mathrm{Xi}=$ Faktor produksi (satuan)

Pxi = Harga faktor produksi (Rp/satuan)

$\mathrm{n} \quad=$ Banyaknya input yang dipakai (satuan)

BTT = Biaya tetap total $(\mathrm{Rp})$

Untuk mengetahui ada atau tidaknya perbedaan pendapatan usahatani padi pada kondisi normal (2014) dan kondisi El Nino (2015), maka digunakan metode analisis uji beda t-test dengan uji hipotesis yakni sebagai berikut:

1) $H_{0}: X_{1}=X_{2}$, tidak terdapat perbedaan pendapatan usahatani padi pada saat kondisi normal dan pada kondisi El Nino.

2) $\mathrm{H}_{1}: \mathrm{X}_{1} \neq \mathrm{X}_{2}$, terdapat perbedaan pendapatan usahatani padi pada saat kondisi normal dan pada kondisi El Nino.

Besarnya manfaat atas korbanan yang dikeluarkan petani padi dihitung dengan analisis rasio penerimaan dan biaya (R/C Ratio). Perhitungan ini ditujukan untuk melihat apakah secara ekonomi menguntungkan atau tidak usahatani padi yang dilakukan pada saat kondisi El Nino. Secara matematis, nilai perbandingan antara penerimaan dan biaya dapat diperoleh menggunakan rumus sebagai berikut:

$\mathrm{R} / \mathrm{C}=(\mathrm{Py} \cdot \mathrm{Y}) /(\mathrm{FC}+\mathrm{VC})$, atau

$\mathrm{R} / \mathrm{C}=\mathrm{PT} / \mathrm{BT}$

Pengkriteriaan penilaian R/C ratio dibagi menjadi tiga kategori, yakni:

1. Jika $\mathrm{R} / \mathrm{C}<1$, maka usahatani yang dilakukan secara ekonomi belum menguntungkan.

2. Jika $\mathrm{R} / \mathrm{C}>1$, maka usahatani yang dilakukan secara ekonomi menguntungkan.

3. Jika $\mathrm{R} / \mathrm{C}=1$, maka usahatani berada pada titik impas (Break Event Point).

Analisis deskriptif kuantitatif digunakan untuk menjelaskan bagaimana pengaruh fenomena El Nino terhadap pola tanam petani. Hasil analisis yakni berupa persentase responden yang terkena dampak dan tidak terkena dampak dari fenomena El Nino terhadap pola tanamnya, serta bagaimana gambaran pola tanam yang diterapkan oleh petani pada tahun sebelum dan pada saat fenomena El Nino terjadi.

Analisis deskriptif kuantitatif digunakan untuk menjelaskan bagaimana upaya mitigasi yang dilakukan oleh petani maupun instansi pemerintah daerah dalam menghadapi fenomena El Nino yang terjadi. Hasil analisis yakni berupa besarnya persentase petani yang melakukan upaya mitigasi dan tidak melakukan upaya mitigasi, serta jenis upaya mitigasi apa saja yang dilakukan petani terhadap fenomena El Nino yang terjadi.

\section{HASIL DAN PEMBAHASAN}

\section{Karakteristik Responden}

Petani responden adalah petani padi yang berasal dari dua desa sampel di Kecamatan Natar, Kabupaten Lampung Selatan yakni Desa Pancasila yang mewakili lahan sawah dengan irigasi pompa dan Desa Negararatu yang mewakili lahan sawah dengan irigasi teknis. Petani responden berjumlah 76 orang yang terbagi menjadi 32 orang di lahan irigasi pompa dan 44 orang di lahan irigasi teknis. Sebagian besar petani adalah petani kecil dan gurem dengan luas lahan sawah kurang dari satu hektar. Sebagian besar petani responden berada pada usia produktif dengan rataan tingkat pendidikan adalah tamat SD. 


\section{Hasil Produksi Usahatani Padi di Daerah Penelitian}

Berdasarkan Tabel 2 tampak bahwa secara statistik produktivitas usahatani padi petani responden lahan irigasi pompa dan lahan irigasi teknis pada saat kondisi normal dan kondisi El Nino tidak memiliki perbedaan yang signifikan. Hal ini terjadi karena pada saat kondisi El Nino petani memiliki sumber air yang ada di dekat lahan sawah mereka dan memanfaatkannya untuk memenuhi kebutuhan usahataninya. Menurut Ivans, Zakaria dan Yanfika (2013), ketersediaan air merupakan faktor utama yang mempengaruhi keberhasilan dan produktivitas usahatani padi sawah.

Keberhasilan usahatani padi memiliki hubungan yang saling berkaitan dengan pencapaian ketahanan pangan nasional. Menurut Sumarno et al. (2008), faktor penentu keberhasilan upaya mencapai ketahanan pangan nasional, selain ketersediaan luas lahan pertanian, juga ketersediaan air pengairan secara empat tepat, yaitu tepat waktu, tepat jumlah, tepat tempat, dan tepat mutu. Sebagian besar sumber air pengairan berasal dari curah hujan, namun karena curah hujan merupakan siklus alamiah yang dipengaruhi oleh banyak faktor, ketiga "tepat" yang pertama sukar diperoleh. Upaya yang dapat dilakukan oleh manusia adalah pengelolaan air tepat mutu.

Harga jual padi pada saat kondisi El Nino di lahan irigasi pompa dan lahan irigasi teknis secara statistik memiliki perbedaan yang signifikan atau mengalami kenaikan dibandingkan dengan pada saat kondisi normal. Perubahan harga yang terjadi tentunya disebabkan oleh beberapa faktor, namun tidak dapat dipungkiri bahwa salah satu penyebabnya adalah karena terjadinya fenomena El Nino di tahun 2015. Hasil uji beda tingkat produktivitas menunjukkan tidak terdapat perbedaan yang signifikan, namun apabila hasil produksi semua responden ditotalkan, maka hasilnya terjadi penurunan total produksi dari pada saat kondisi normal ke kondisi El Nino. Total produksi yang menurun inilah yang menyebabkan harga padi pada saat kondisi El Nino mengalami kenaikan.

Hasil ini juga sama dengan hasil penelitian Medika, Abidin dan Kasymir (2016) yang menyatakan bahwa tanaman singkong yang menjadi bahan baku pembuatan kelanting dan keripik singkong memiliki harga yang lebih tinggi pada saat kondisi El Nino dibandingkan dengan pada saat kondisi normal.
Tabel 2. Rata-rata per hektar dan uji beda hasil produksi, harga dan penerimaan usahatani padi pada MT 2 kondisi normal dan kondisi El Nino di Kecamatan Natar Kabupaten Lampung Selatan

\begin{tabular}{lllrrr}
\hline No & $\begin{array}{l}\text { Kelompok } \\
\text { responden }\end{array}$ & Kondisi & $\begin{array}{c}\text { Produksi } \\
\text { padi } \\
\text { (kg/ha) }\end{array}$ & $\begin{array}{c}\text { Harga } \\
\text { padi } \\
(\mathrm{Rp} / \mathrm{kg})\end{array}$ & $\begin{array}{c}\text { Penerimaan } \\
(\mathrm{Rp} / \mathrm{ha})\end{array}$ \\
\hline 1. & Lahan irigasi & Normal & 4.915 & 3.552 & 17.458 .613 \\
& pompa & El Nino & 4.688 & 3.743 & 17.418 .679 \\
\hline \multicolumn{2}{l}{ Sig. (2-tailed) } & & 0,252 & 0,000 & 0,940 \\
\hline 2. & Lahan irigasi & Normal & 5.291 & 3.797 & 20.166 .274 \\
& teknis & El Nino & 5.259 & 3.934 & 20.722 .877 \\
\hline \multicolumn{2}{l}{ Sig. (2-tailed) } & 0,763 & 0,000 & 0,194 \\
\hline
\end{tabular}

Penerimaan usahatani padi petani responden lahan irigasi pompa dan lahan irigasi teknis pada saat kondisi normal dan kondisi El Nino secara statistik tidak memiliki perbedaan yang signifikan. Hal ini terjadi dikarenakan pada saat kondisi El Nino, hasil produksi padi tetap dapat optimal dan harga jual padi juga yang mengalami peningkatan dibandingkan pada saat kondisi normal. Sehingga, penerimaan usahatani padi yang diperoleh dari hasil produksi dikali dengan harga jual padi pada saat kondisi El Nino dapat tetap optimal dan tidak memiliki perbedaan yang signifikan bila dibandingkan dengan pada saat kondisi normal.

\section{Analisis Uji Beda Pendapatan Usahatani Padi pada saat Kondisi Normal dan Kondisi EI Nino}

Hasil analisis uji beda pendapatan usahatani padi yang tertera pada Tabel 3 menunjukkan bahwa tidak terdapat perbedaan yang signifikan antara pendapatan usahatani padi pada saat kondisi normal dan kondisi El Nino. Hasil ini berbeda dengan hipotesis yang diajukan di dalam penelitian ini yakni diduga pendapatan usahatani padi pada saat kondisi normal lebih besar dibandingkan dengan pada saat kondisi El Nino.

Perbedaan antara hasil penelitian dengan hipotesis yang diajukan terjadi, dikarenakan petani lahan irigasi pompa dan lahan irigasi teknis tidak menggantungkan kebutuhan airnya hanya pada hujan, melainkan petani juga memiliki sumber air yang ada di dekat lahan sawah. Petani mampu melakukan upaya mitigasi berupa penambahan air dari sumber air yang ada menggunakan mesin pompa. Akibatnya, hal ini berdampak baik pada kegiatan usahatani yakni produktivitas padi pada saat kondisi El Nino dapat terjaga optimal dan tidak jauh berbeda dengan produktivitas padi pada saat kondisi normal. 
Tabel 3. Uji beda pendapatan usahatani padi petani responden pada MT 2 kondisi normal dan kondisi El Nino di Kecamatan Natar Kabupaten Lampung Selatan

\begin{tabular}{ccrr}
\hline No & Kelompok responden & t-hitung & Sig. (2-tailed) \\
\hline 1 & Lahan irigasi pompa & 0,416 & 0,679 \\
2 & Lahan irigasi teknis & $-0,995$ & 0,327 \\
\hline
\end{tabular}

Hasil ini juga didukung oleh penelitian Utami et al. (2011) yang mengkaji El Nino, La Nina, dan penawaran pangan di Jawa yang menyimpulkan bahwa anomali iklim El Nino menurunkan produksi padi dengan persentase penurunan produksi padi dalam setahun sebesar $-4,15$ persen. Namun apabila dikaji secara lebih spesifik, penurunan produksi padi akibat El Nino hanya terjadi pada periode bulan Januari-April dan
September-Desember. Ketika periode bulan MeiAgustus, produksi padi mengalami peningkatan sebesar 4,22 persen.

Tabel 4 menunjukkan bahwa pada kedua kelompok responden, rata-rata produksi padi mengalami sedikit penurunan dari pada saat kondisi normal ke kondisi El Nino. Rata-rata penerimaan petani pada saat kondisi El Nino tidak jauh berbeda dengan pada saat kondisi normal, bahkan pada lahan irigasi teknis mengalami peningkatan dikarenakan harga jual padi yang lebih besar. Rata-rata total biaya yang dikeluarkan petani pada saat kondisi El Nino lebih besar dibandingkan dengan pada saat kondisi Normal. Rata-rata pendapatan yang diperoleh petani pada saat kondisi El Nino tidak jauh berbeda dengan pada saat kondisi normal.

Tabel 4. Analisis pendapatan usahatani padi per hektar di Kecamatan Natar Kabupaten Lampung Selatan pada MT 2 kondisi normal dan kondisi El Nino

\begin{tabular}{|c|c|c|c|c|c|c|c|c|c|}
\hline \multirow{3}{*}{ No } & \multirow{3}{*}{ Uraian } & \multicolumn{4}{|c|}{ Lahan irigasi pompa } & \multicolumn{4}{|c|}{ Lahan irigasi teknis } \\
\hline & & \multicolumn{2}{|c|}{ Normal } & \multicolumn{2}{|c|}{ El Nino } & \multicolumn{2}{|r|}{ Normal } & \multicolumn{2}{|c|}{ El Nino } \\
\hline & & Fisik & Nilai (Rp) & Fisik & Nilai (Rp) & Fisik & Nilai (Rp) & Fisik & Nilai (Rp) \\
\hline \multirow[t]{2}{*}{1.} & Penerimaan & & & & & & & & \\
\hline & Produksi Padi & 4.915 & 17.458 .613 & 4.688 & 17.418 .679 & 5.291 & 20.166 .274 & 5.259 & 20.722 .877 \\
\hline \multirow[t]{30}{*}{2.} & Biaya Produksi & & & & & & & & \\
\hline & I. Biaya Tunai & & & & & & & & \\
\hline & Benih (kg) & 33 & 414.080 & 33 & 437.979 & 39 & 406.515 & 39 & 406.515 \\
\hline & Pupuk & & & & & & & & \\
\hline & a. Pupuk Urea $(\mathrm{kg})$ & 208 & 430.167 & 208 & 446.982 & 239 & 494.104 & 239 & 507.017 \\
\hline & b. Pupuk Organik (kg) & 4 & 13.317 & 4 & 12.784 & - & - & - & - \\
\hline & c. Pupuk TSP $(\mathrm{kg})$ & 95 & 222.763 & 106 & 246.484 & 107 & 243.691 & 107 & 247.700 \\
\hline & d. Pupuk KCL (kg) & 2 & 12.784 & 2 & 12.234 & - & - & - & - \\
\hline & e. Pupuk ZA (kg) & 4 & 5.717 & 4 & 6.854 & 11 & 15.448 & 11 & 15.448 \\
\hline & f. Pupuk NPK $(\mathrm{kg})$ & 151 & 392.880 & 156 & 429.102 & 172 & 431.781 & 172 & 455.159 \\
\hline & Obat-obatan Pertanian & & & & & & & & \\
\hline & a. Furadan 3 GR (gr) & 3.196 & 59.375 & 3.125 & 58.026 & 4.363 & 85.142 & 4.835 & 92.983 \\
\hline & b. Regent $50 \mathrm{SC}(\mathrm{ml})$ & 224 & 80.788 & 213 & 70.845 & 271 & 96.993 & 236 & 86.675 \\
\hline & c. Prevathon $50 \mathrm{EC}(\mathrm{ml})$ & 192 & 118.075 & 203 & 126.953 & 195 & 122.642 & 165 & 107.311 \\
\hline & d. Fungisida (gr) & 195 & 26.708 & 213 & 29.830 & 310 & 43.337 & 280 & 39.210 \\
\hline & e. Raft (ml) & 522 & 25.391 & 504 & 22.550 & 696 & 34.788 & 672 & 33.608 \\
\hline & f. Roundup (ml) & 426 & 54.688 & 451 & 57.138 & 483 & 62.854 & 483 & 62.854 \\
\hline & TK Luar Keluarga (HOK) & 80 & 4.033 .514 & 81 & 4.052 .703 & 89 & 4.522 .897 & 91 & 4.602 .412 \\
\hline & Biaya Lain-lain & & & & & & & & \\
\hline & a. Biaya Pajak/Musim (Rp) & & 21.591 & & 21.591 & & 36.291 & & 36.291 \\
\hline & b. Biaya Sewa Pompa Air (Rp) & & 1.235 .795 & & 1.235 .795 & & 1.049 .528 & & 1.049 .528 \\
\hline & c. Biaya Sewa Bajak/Musim (Rp) & & 765.270 & & 775.923 & & 612.854 & & 612.854 \\
\hline & d. Biaya Mitigasi (Rp) & & - & & 170.099 & & & & 140.330 \\
\hline & Total Biaya Tunai & & 7.912 .903 & & 8.213 .871 & & 8.258 .864 & & 8.495 .897 \\
\hline & II. Biaya Dip & & & & & & & & \\
\hline & TK Dalar & 8 & 381.614 & 8 & 381.614 & 9 & 450.521 & 9 & 450.521 \\
\hline & Sewa Lahan (Rp) & & 2.494 .673 & & 2.494 .673 & & 2.507 .370 & & 2.507 .370 \\
\hline & Penyusu & & 142.970 & & 128.066 & & 198.162 & & 162.048 \\
\hline & Diperhitungkan & & 3.019 .258 & & 3.004 .353 & & 3.156 .053 & & 3.119 .939 \\
\hline & III. Total Biaya & & 10.932 .160 & & 11.218 .224 & & 11.414 .917 & & 11.615 .836 \\
\hline \multirow[t]{3}{*}{3.} & Pendapatan & & & & & & & & \\
\hline & I. Pendapatan Atas Biay & & 9.545 .710 & & 9.204 .808 & & 11.907 .410 & & 12.226 .981 \\
\hline & II. Pendapatan Atas Biaya Total & & 6.526 .453 & & 6.200 .455 & & 8.751 .356 & & 9.107 .042 \\
\hline
\end{tabular}




\section{Analisis Perbandingan R/C Ratio}

Rata-rata nilai $\mathrm{R} / \mathrm{C}$ atas biaya total usahatani padi pada saat kondisi normal adalah sebesar 1,69 dan pada saat kondisi El Nino adalah sebesar 1,67. Artinya setiap satu rupiah biaya total yang dikeluarkan petani pada kondisi normal akan memperoleh penerimaan sebesar 1,69 dan setiap satu rupiah biaya total yang dikeluarkan petani pada kondisi El Nino akan memperoleh penerimaan sebesar 1,67. Petani yang melakukan usahatani padi pada kondisi normal dan kondisi El Nino memperoleh nilai $\mathrm{R} / \mathrm{C}>1$ yang dapat dikatakan menguntungkan dan layak untuk dikembangkan, namun nilai efisiensi usahatani pada saat kondisi normal lebih baik dibandingkan dengan pada saat kondisi El Nino. Hal itu dapat dilihat dari nilai $\mathrm{R} / \mathrm{C}$ usahatani pada saat kondisi normal lebih besar dibandingkan usahatani pada saat kondisi El Nino dengan selisih yang relatif kecil yakni sebesar 0,02 .

\section{Dampak Fenomena El Nino terhadap Pola Tanam}

Berdasarkan Gambar 2 tampak bahwa di daerah lahan irigasi pompa, rata-rata petani dapat menanam komoditas padi dua kali dalam satu tahun dikarenakan kebutuhan air dapat terpenuhi. Petani mengawali MT 1 pada usahatani tahun 2014/2015 (kondisi El Nino) yakni dari bulan Desember hingga Maret, dimana ketersediaan air dapat terpenuhi yang bersumber dari hujan dan irigasi sumur bor. Kemudian petani mengawali MT 2 pada usahatani tahun 2014/2015 (kondisi El Nino) yakni dari bulan April hingga Juli, dimana ketersediaan air juga masih terpenuhi yang bersumber dari irigasi sumur bor, meskipun memerlukan tambahan biaya dalam penggunaan pompa air. Petani mengawali MT 3 pada usahatani tahun 2014/2015 (kondisi El Nino) yakni dari bulan Agustus hingga Oktober dengan menanam tanaman palawija yakni cabai dan tomat.

Sementara pola tanam daerah lahan irigasi pompa pada saat kondisi normal tidak berbeda dengan pola tanam pada saat kondisi El Nino. Dampak fenomena El Nino yang terjadi di tahun 2015 sedikit mempengaruhi aktivitas usahatani padi yakni lahan sawah menjadi lebih kering. Namun, hal ini tidak berpengaruh terhadap pola tanam, dikarenakan petani melakukan upaya mitigasi berupa penambahan intensitas penggunaan pompa air, sehingga kekurangan air akibat kekeringan dapat terpenuhi dan pola tanam dapat tetap terjaga seperti pada saat kondisi normal.
Usahatani Tahun 2013/2014

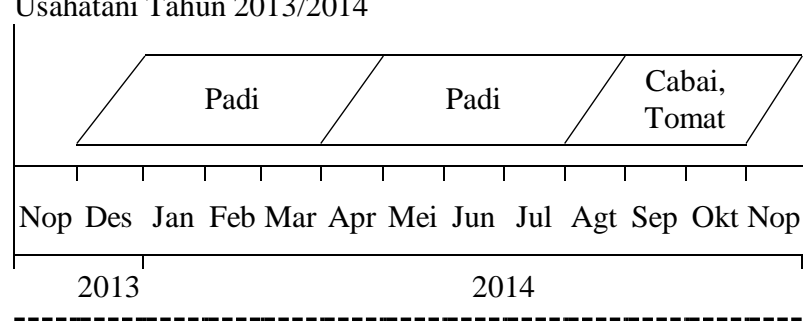

Usahatani Tahun 2014/2015

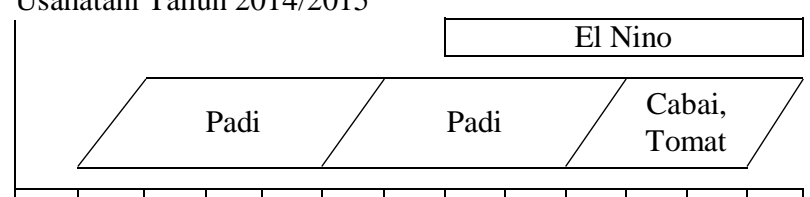

Nop Des Jan Feb Mar Apr Mei Jun Jul Agu Sep Okt Nop 2014 2015

Gambar 2. Pola tanam petani responden lahan irigasi pompa pada kondisi normal (tahun 2013/2014) dan kondisi El Nino (tahun 2014/2015)

Berdasarkan Gambar 3 tampak bahwa di daerah lahan irigasi teknis, rata-rata petani dapat menanam komoditas padi dua kali dalam satu tahun. Hal ini dikarenakan ketersediaan air yang dibutuhkan selama proses usahatani dapat terpenuhi. Petani mengawali MT 1 pada usahatani tahun 2014/2015 (kondisi El Nino) yakni dari bulan Desember hingga Maret, dimana ketersediaan air dapat terpenuhi yang bersumber dari hujan dan irigasi. Kemudian petani mengawali MT 2 pada usahatani tahun 2014/2015 (kondisi El Nino) yakni dari bulan April hingga Juli, dimana ketersediaan air juga masih terpenuhi yang bersumber dari air irigasi, meskipun memerlukan tambahan biaya dalam penggunaan pompa air. Petani mengawali MT 3 pada usahatani tahun 2014/2015 (kondisi El Nino) yakni dari bulan Agustus hingga Oktober dengan menanam tanaman palawija yakni cabai dan timun.

Pola tanam daerah lahan irigasi teknis pada saat kondisi normal tidak berbeda dengan pola tanam pada saat kondisi El Nino. Dampak fenomena El Nino yang terjadi di tahun 2015 sedikit mempengaruhi aktivitas usahatani padi yakni lahan sawah menjadi lebih kering dibandingkan dengan pada saat kondisi normal. Namun, hal ini tidak berpengaruh terhadap pola tanam dikarenakan petani melakukan upaya mitigasi berupa penambahan intensitas penggunaan pompa air, sehingga kekurangan air yang terjadi akibat adanya kekeringan di lahan sawah dapat terpenuhi dan pola tanam dapat tetap terjaga seperti pada saat kondisi normal. 
Usahatani Tahun 2013/2014

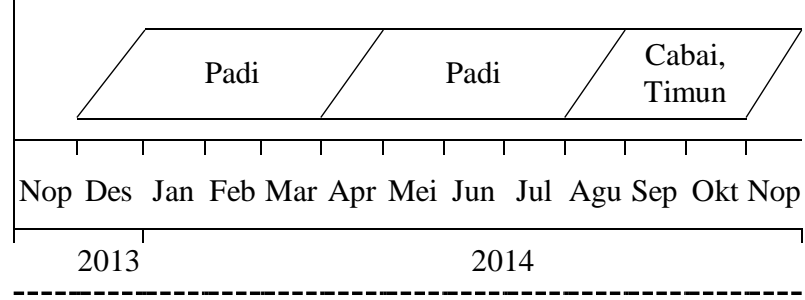

Usahatani Tahun 2014/2015

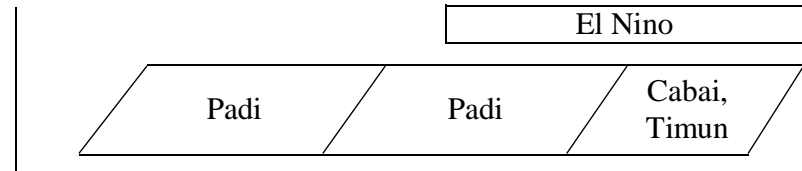

Nop Des Jan Feb Mar Apr Mei Jun Jul Agu Sep Okt Nop 2014

2015

Gambar 3. Pola tanam petani responden lahan irigasi teknis pada kondisi normal (tahun 2013/2014) dan kondisi El Nino (tahun 2014/2015)

\section{Upaya Mitigasi oleh Petani}

Upaya mitigasi yang dilakukan oleh petani ialah mendistribusikan air dari sumber air ke lahan sawah menggunakan mesin pompa air. Alasan petani menggunakan mesin pompa air, dikarenakan dampak kekeringan akibat fenomena El Nino sangat erat kaitannya dengan besarnya kebutuhan air oleh tanaman padi. Selain itu, terdapatnya sumber air yang berasal dari irigasi teknis ataupun irigasi pompa juga menjadi alasan para petani menggunakan mesin pompa air.

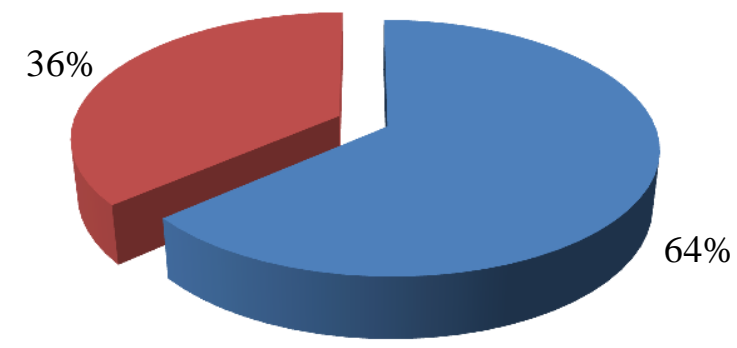

- 64 persen menambah intensitas penggunaan air menggunakan pompa air

- 36 persen tidak ada upaya mitigasi

Gambar 4. Upaya mitigasi petani responden lahan irigasi pompa terhadap kemungkinan dampak dari fenomena El Nino di Kecamatan Natar Kabupaten Lampung Selatan, 2015

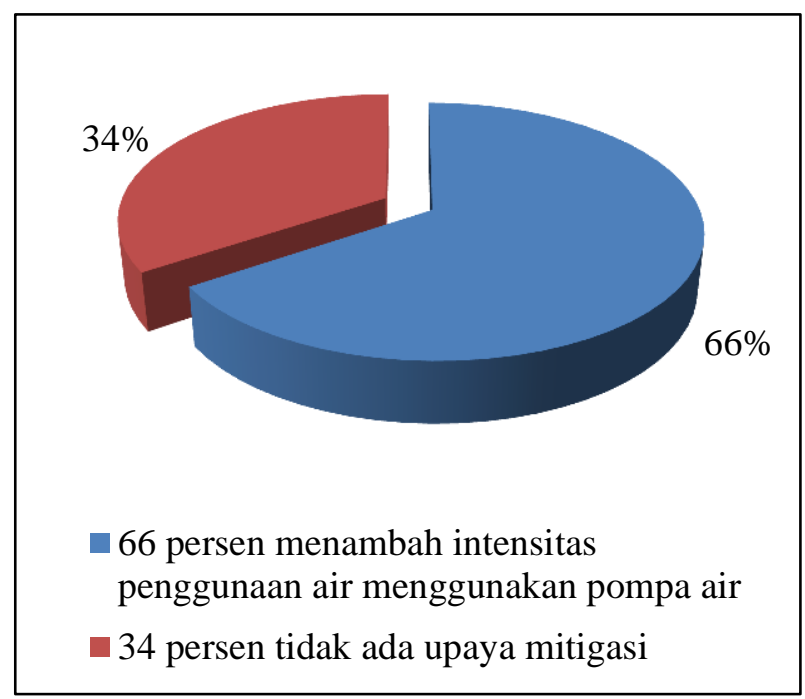

Gambar 5. Upaya mitigasi petani responden lahan irigasi teknis terhadap kemungkinan dampak dari fenomena El Nino di Kecamatan Natar Kabupaten Lampung Selatan, 2015

Berdasarkan Gambar 4, tampak hasil perhitungan besarnya persentase petani yang melakukan upaya mitigasi dan tidak melakukan upaya mitigasi di lahan irigasi pompa yang menyatakan bahwa mayoritas petani atau sebesar 64 persen petani melakukan upaya mitigasi dengan menambah intensitas penggunaan air menggunakan pompa air dan sisanya sebesar 36 persen petani tidak melakukan upaya mitigasi.

Berdasarkan Gambar 5 tampak hasil perhitungan besarnya persentase petani yang melakukan upaya mitigasi dan tidak melakukan upaya mitigasi di lahan irigasi teknis yang menyatakan bahwa 66 persen petani melakukan upaya mitigasi dengan menambah intensitas penggunaan air menggunakan pompa air. Sementara sisanya sebesar 34 persen petani tidak melakukan upaya mitigasi.

Jenis upaya mitigasi yang dilakukan oleh petani pada saat kondisi El Nino di Kecamatan Natar sama dengan hasil penelitian Nopralita, Abidin dan Affandi (2017) yang menyatakan bahwa jenis upaya mitigasi yang paling banyak dilakukan oleh petani pada saat kondisi El Nino adalah dengan menggunakan mesin pompa air. Keberhasilan upaya mitigasi ditunjukkan dari penilaian masingmasing individu petani terhadap hasil yang dirasakan setelah melakukan upaya mitigasi. Berdasarkan hasil penelitian, sebagian besar petani merasakan keberhasilan terhadap upaya mitigasi yang telah dilakukan. Salah satu keberhasilan yang 
dirasakan oleh petani adalah tidak ada perbedaan yang signifikan antara pendapatan petani pada saat kondisi normal dan pada saat kondisi El Nino.

\section{KESIMPULAN}

Dampak fenomena El Nino tidak berpengaruh terhadap pendapatan usahatani padi dan pola tanam petani padi di Kecamatan Natar. Upaya mitigasi yang dilakukan oleh petani adalah melakukan penambahan biaya penggunaan mesin pompa air.

\section{DAFTAR PUSTAKA}

Ariani R. 2011. Kegunaan data anomali suhu muka laut pasifik (nino 3,4) untuk prediksi produksi padi di Indonesia. Skripsi. Institut Pertanian Bogor. Bogor.

BMKG [Badan Meteorologi Klimatologi dan Geofisika]. 2015. Monitoring Perkembangan El Nino 2015 dan Antisipasi Dampaknya di Indonesia. BMKG. Jakarta. http://data.bmkg .go.id/share/Dokumen/ekspose\%20antisipasi \%20el\%20nino_kpk_web.pdf. [20 Februari 2016].

BMKG [Badan Meteorologi Klimatologi dan Geofisika] Provinsi Lampung. 2015. Jumlah Curah Hujan Provinsi Lampung Tahun 20112015. BMKG Provinsi Lampung. Lampung Selatan.

BPS [Badan Pusat Statistik] Kabupaten Lampung Selatan. 2016. Luas Panen dan Produksi Padi (Padi Sawah dan Padi Ladang) menurut Kecamatan di Kabupaten Lampung Selatan Tahun 2015. BPS Kabupaten Lampung Selatan. Lampung Selatan.

BPS [Badan Pusat Statistik] Provinsi Lampung. 2015. Luas Panen, Produksi, Produktivitas Padi menurut Kabupaten/Kota di Provinsi Lampung Tahun 2014. BPS Provinsi Lampung. Lampung.

Festiani RA. 2011. Dampak perubahan iklim terhadap pendapatan dan faktor-faktor penentu adaptasi petani terhadap perubahan iklim. Skripsi. Institut Pertanian Bogor. Bogor.

Husein U. 2004. Metode Penelitian untuk Skripsi dan Tesis Bisnis. PT Raja Grafindo Persada. Jakarta.
Irawan B. 2006. Fenomena anomali iklim el nino dan la nina: kecenderungan jangka panjang dan pengaruhnya terhadap produksi pangan. Jurnal Agro Ekonomi, 24 (1) : 28-45. http://pse.litbang.pertanian.go.id/ind/pdffile. [25 Februari 2016].

Ivans E, Zakaria WA, dan Yanfika H. 2013. Analisis usahatani padi sawah pada irigasi desa di Kecamatan Purbolinggo Kabupaten Lampung Timur. JIIA, 1 (3) : 238-245. http://jurnal.fp.unila.ac.id/index.php/JIA/articl e/view/579/541. [20 Juni 2016].

Medika C, Abidin Z, dan Kasymir E. 2016. Dampak el nino terhadap produksi dan pendapatan agroindustri berbasis singkong di Desa Karang Anyar Kecamatan Gedongtataan Kabupaten Pesawaran. JIIA, 4 (4) : 351-358. http://jurnal.fp.unila.ac.id/index.php/JIA/art icle/view/1516/1370. [20 Maret 2018].

Nopralita, Abidin Z, dan Affandi MI. 2017. Dampak el nino terhadap pendapatan rumah tangga petani padi di Kecamatan Punggur, Kabupaten Lampung Tengah. JIIA, 5 (2) : 179-183. http://jurnal.fp.unila.ac.id/index. php/JIA/article/view/1656/1482. [20 Maret 2018].

Rahim A dan Hastuti DRD. 2007. Ekonomi Pertanian. Penebar Swadaya. Jakarta.

Soekartawi, Soeharjo A, Dillon JL, dan Hardaker JB. 2011. Ilmu Usahatani dan Penelitian Untuk Pengembangan Petani Kecil. UI Press. Jakarta.

Sugiarto, Siagian D, Sunarto LS, dan Oetomo DS. 2003. Teknik Sampling. Gramedia Pustaka Utama. Jakarta.

Sugiyono. 2012. Metode Penelitian Kuantitatif Kualitatif dan $R \& B$. Alfabeta. Bandung.

Sumarno, et al. 2008. Anomali iklim 2006/2007 dan saran kebijakan teknis pencapaian target produksi padi. Iptek Tanaman Pangan, 3 (1) : 69-97. http://ejurnal.litbang.pertanian.go.id/ index.php/ippan/article/view/2652/2291. [1 April 2018].

Utami AW, Jamhari, dan Hardyastuti S. 2011. El nino, la nina, dan penawaran pangan di Jawa, Indonesia. Jurnal Ekonomi Pembangunan, 12 (2): 257-271. http://journals.ums.ac.id/index .php/JEP/article/view/197/184. [25 Februari 2016]. 